\title{
Locally aggressive monostotic fibrous dysplasia of the cervical spine mimicking malignancy: a case report and literature review
}

\author{
Audrey Milon ${ }^{1, *}$, Marc Polivka $^{2}$, Fréderique Larousserie $^{3}$, Guillaume Lot $^{4}$, Jean-Marc Ziza ${ }^{5}$, \\ and Jean-Denis Laredo ${ }^{1}$ \\ 1 Department of Radiology, Hôpital Lariboisière, Assistance Publique des Hôpitaux de Paris, 2 rue Ambroise Paré, 75010 Paris, France \\ 2 Department of Pathology, Hôpital Lariboisière, Assistance Publique des Hôpitaux de Paris, 2 rue Ambroise Paré, 75010 Paris, France \\ 3 Department of Pathology, Hôpital Cochin, Assistance Publique des Hôpitaux de Paris, 27 rue du Faubourg Saint-Jacques, 75014 Paris, \\ France \\ ${ }_{5}^{4}$ Department of Neurosurgery, Fondation Ophtalmologique de Rothschild, 29 rue Manin, 75019 Paris, France \\ 5 Department of Rheumatology, Hôpital La Croix Saint-Simon, 125 rue d'Avron, 75020 Paris, France
}

Received 4 July 2019, Accepted 7 July 2019, Published online 27 September 2019

\begin{abstract}
We report the case of a 30-year-old woman with histologically proven monostotic fibrous dysplasia of C2 revealed by a pathological fracture of the odontoid process. Radiological investigations showed a ground-glass mineralization of the vertebral body, a centimetric lytic area with poorly defined margins involving the inferior part of the vertebral body and inferior endplate and a fracture through an osteolytic area in the base of the odontoid process. Owing to the vertebral instability, a surgical procedure combining $\mathrm{C} 0-\mathrm{C} 5$ fixation and posterior bone grafting was performed. The surgical biopsy was inconclusive and pathological confirmation was finally obtained through a percutaneous needle biopsy under fluoroscopic guidance. At 26-month follow-up, the patient still experienced mild persistent cervical posterior neck pain and stiffness possibly related to a C5-6 laxity below the intervertebral fixation.

This case combines three radiological findings, which are unusual in fibrous dysplasia: monostotic presentation involving the spine, some aggressive radiographic features, and a pathological fracture.
\end{abstract}

Key words: Monostotic fibrous dysplasia, Cervical spine, Pathological fracture, Aggressive.

\section{Introduction}

Fibrous dysplasia (FD) is a non-neoplastic tumor-like congenital process characterized by a localized defect in osteoblastic differentiation and maturation, with replacement of normal bone with large fibrous stroma and islands of immature woven bone. It is subclassified as monostotic and polyostotic lesions [1]. The spine is affected in only $2.5 \%$ of cases [2] and monostotic FD of the spine is uncommon. This case report covers the diagnosis and treatment of a patient with monostotic FD of $\mathrm{C} 2$ with a mixed osteosclerotic and osteolytic radiologic appearance, which was revealed by a pathological fracture of the odontoid process.

\section{Case report}

The patient was a 30-year-old woman who presented with a considerable spontaneous pain in the upper neck. She had no

\footnotetext{
*Corresponding author: audrey.milon. am@gmail.com
}

other significant medical history. Physical examination revealed a cervical stiffness without neurologic signs or symptoms. Radiographs of the cervical spine revealed a pathological fracture involving the odontoid process of C2. CT confirmed the fracture of the odontoid process and the replacement of normal bone by ground-glass mineralization and a centimetric lytic area with poorly defined margins involving the inferior part of the vertebral body and inferior endplate (Figure 1).

MRI of the cervical spine revealed low signal intensity of the whole $\mathrm{C} 2$ vertebra on both $\mathrm{T} 1$ - and $\mathrm{T} 2$-weighted images, with mild homogenous enhancement after gadolinium administration that suggested a fibrous and/or mineralized content (Figure 2). There was no soft tissue extension and the $\mathrm{C} 2-3$ intervertebral disc was normal. Standard blood laboratory investigations, including C-reactive protein level, gave normal serum values. A full metastatic imaging workup including whole-body CT revealed no other abnormal findings.

Owing to the odontoid process fracture and the vertebral instability, a surgical procedure combining $\mathrm{C} 0-\mathrm{C} 5$ fixation and posterior bone grafting was decided. The surgery was 


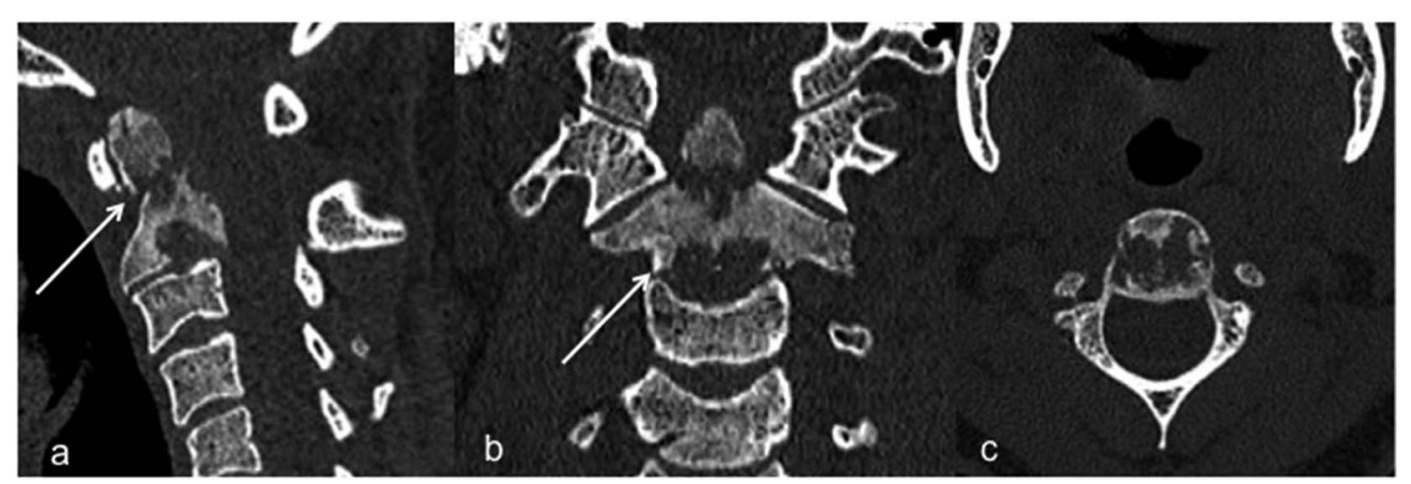

Figure 1. (a) Sagittal, (b) coronal and (c) axial CT-scan reformations of the upper cervical spine in a 30-year-old woman, showing the mixed appearance of the $\mathrm{C} 2$ vertebral body with a ground-glass appearance and osteolytic areas in the base of the odontoid process with a pathologic fracture (thin arrow) and in the inferior part of the vertebral body with partial destruction of the inferior endplate (thick arrow).

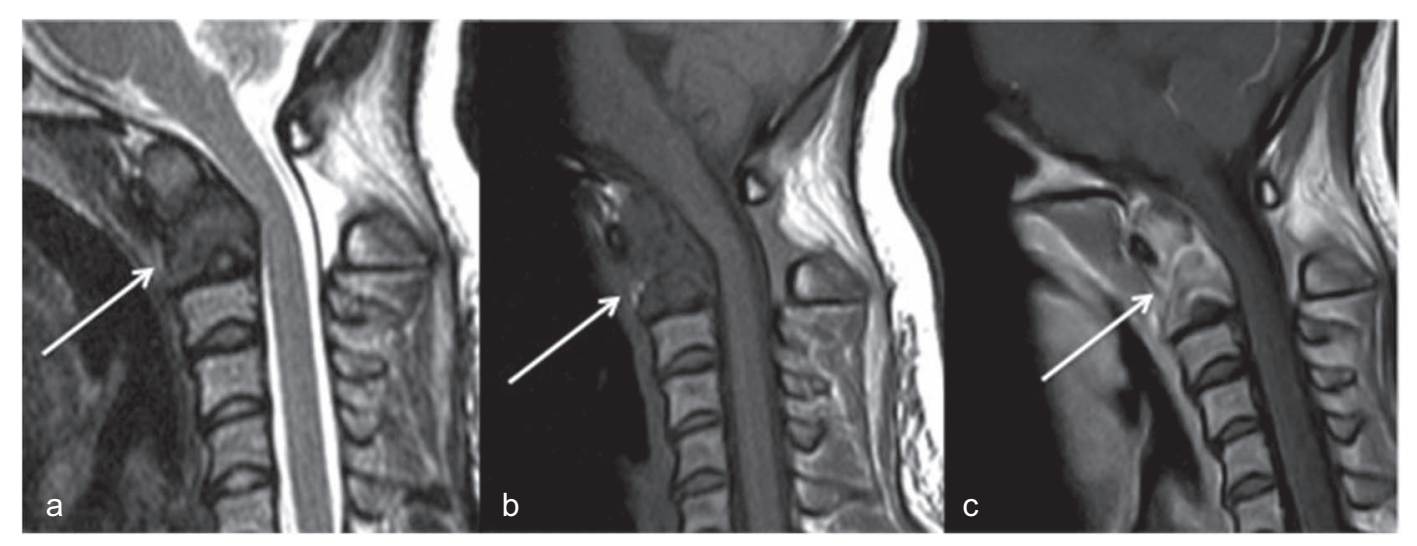

Figure 2. T2-weighted, T1-weighted, T1-weighted with intra-venous contrast administration midline sagittal MR images of the cervical spine showing the low signal intensity of the $\mathrm{C} 2$ vertebral body and odontoid process (a, b), with enhancement after contrast administration (c), and a solution at the junction between the odontoid process and vertebral body $(\mathrm{a}-\mathrm{c})$.

performed in the prone position and under general anesthesia. The neural arch of $\mathrm{C} 2$ was resected up to the lateral masses, and the bone resected was sent for pathological and bacteriological examinations. Screws (4.5-mm diameter, 12-mm size) were inserted in lateral masses of C3, C4, and C5 bilaterally according to the technique of Roy-Camille. Two vertical rods connected to an occipital plate were then fixed to $\mathrm{C} 3, \mathrm{C} 4$, and C5 screws and the plate was fixed to the occiput, thanks to three screws bilaterally. An autologous bone graft was withdrawn from the posterior iliac crest and placed from occiput to C3. Pathological examination of the resected bone was inconclusive as well as microbiology for Gram staining and bacteriological cultures including acid-fast bacilli and fungal assays. Therefore, a percutaneous needle biopsy of the osteolytic inferior part of the $\mathrm{C} 2$ vertebral body was performed under local anesthesia and fluoroscopic guidance. A 11-gauge 10-cm-long coaxial biopsy needle (KBC1110, Merit Medical ${ }^{\circledR}$, Galway, Ireland) was advanced up to $\mathrm{C} 2$ vertebral body through an anterolateral ascending approach between the jugulo-carotid bundle and the trachea-oesophagus, and bone samples from $\mathrm{C} 2$ vertebral body were obtained (Figure 3). The final pathological diagnosis was FD, confirmed by a pathological review in a second institution. No secondary aneurysmal bone cyst and no sign of malignant transformation were seen. The patient received intravenous pamidronate (60 mg/day over 3 days every 6 months). At 3-month follow-up, the patient was doing well, except for mild cervical posterior neck pain and a follow-up radiograph showed that the fixation material was in good position. Some widening of the C5-6 facet joints, which could correspond to joint laxity below the fixed cervical levels, was noted. At 26-month followup, the patient still experienced mild persistent cervical posterior neck pain and stiffness, possibly related to the C5-6 laxity. Since the patient was pregnant at this last consultation, static and dynamic radiographic examinations as well as discussion of an indication of a C5-6 anterior joint fusion were postponed.

\section{Discussion}

FD is a genetic, non-inherited condition with no sex predilection that results in a somatic mosaicism of affected osteoblastic cells producing a poorly organized fibrous connective tissue interwoven with trabeculae of immature bone [3]. It appears to be caused by mutations in the GNAS1 gene that encodes for the alpha subunit of the stimulatory G-protein Gs [4]. 


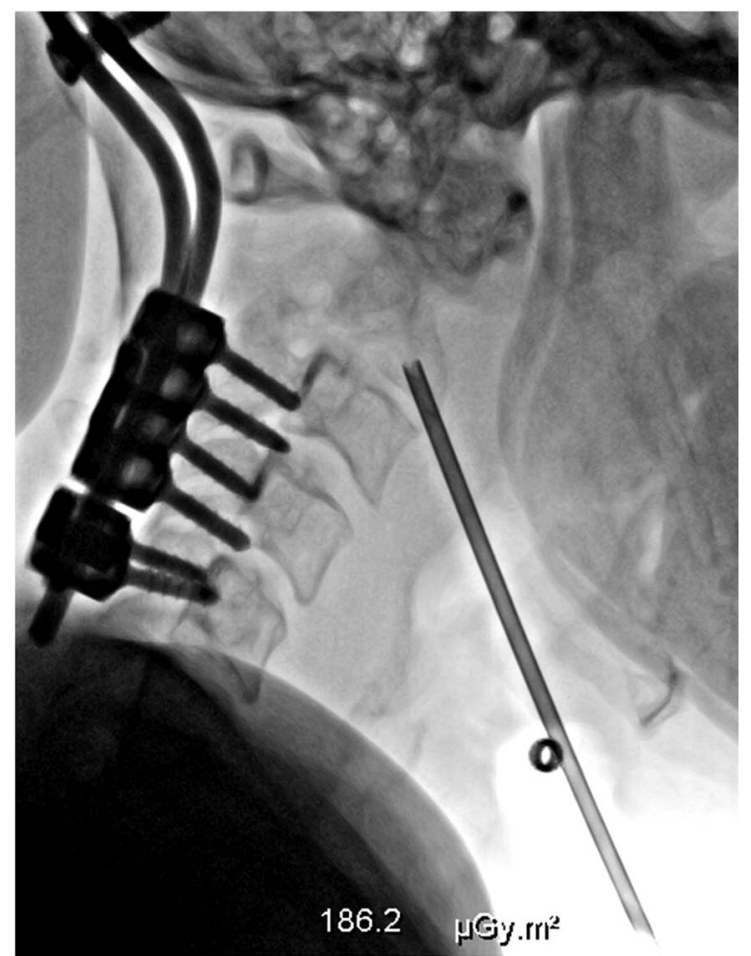

Figure 3. Percutaneous needle biopsy of $\mathrm{C} 2$ under fluoroscopic guidance with an anterolateral approach.

We report a case of monostotic FD of C2 in a 30-year-old woman with a locally aggressive radiologic appearance, which was revealed by a pathological fracture of the odontoid process.
The spine accounts for only $1.4 \%$ of cases of monostotic FD [5]. Including ours, 18 cases of monostotic FD involving the cervical spine have been previously reported to our knowledge [6-20]. These 18 cases concerned 13 males and five females, most commonly in the third to fifth decades of life (mean age 32.5 years [range 11-56]), and involved $\mathrm{C} 2$ in seven cases (39\%), C4 in five cases, $\mathrm{C} 1$ in three cases, and C3, C6, and $\mathrm{C} 7$ in one case each. Patients most commonly presented with axial neck or back pain, but in some cases, FD was an incidental finding. Only one patient had neurological symptoms, i.e. a 35-year-old man who presented a cervico-brachial neuralgia with sensitive symptoms.

Cervical FD may be revealed by a pathological fracture. Back to 1989, 11 cases including ours (mean age 37 years [range 17-63) of monostotic $(n=4)$ or polyostotic $(n=7)$ FD of the cervical spine revealed by a pathological fracture have been reported (Table 1). Interestingly, 5 out of the 11 cases involved C2. Only one of these was monostotic.

CT features of vertebral FD do not differ from those of extraspinal location and included well-defined predominantly osteolytic lesions with ground-glass mineralization, sclerotic rim formation, an expansile nature with bone remodeling, and rarely cortical disruption. Vertebral body weight loss is frequent [21]. On T1-weighted images, low signal intensity is present in $67 \%$ of the lesions and heterogeneous signal intensity in $33 \%$. On T2-weighted images, lesions show heterogeneous signal intensity with a low signal intensity rim in half of the cases; after intravenous gadolinium administration, lesion enhancement is homogeneous in $50 \%$ of cases and heterogeneous in $50 \%$ [21]. This diversity of the MR findings in FD is explained by their variable contents in bony trabeculae, cellularity, collagen fibers, cystic changes, and hemorrhage [22].

Table 1. Reported cases of cervical spine fibrous dysplasia presenting with a pathological fracture.

\begin{tabular}{|c|c|c|c|c|c|c|c|}
\hline Report & Sex & Age & $\begin{array}{l}\text { Neurological } \\
\text { symptoms }\end{array}$ & Location & $\begin{array}{l}\text { Monostotic/ } \\
\text { polyostotic }\end{array}$ & Treatment & Follow-up (month) \\
\hline Our case & $\mathrm{F}$ & 31 & No & $\mathrm{C} 2$ & Monostotic & $\begin{array}{l}\text { Bone graft; posterior } \\
\text { fixation }\end{array}$ & $\begin{array}{l}\text { Asymptomatic at } 18 \text { months } \\
\text { follow-up }\end{array}$ \\
\hline \multirow[t]{4}{*}{ Wu et al. [20] } & M & 48 & No & $\mathrm{C} 2-\mathrm{C} 3$ & $\begin{array}{c}\text { Monostotic } \\
\text { (non-segmentation } \\
\text { of C2-C3) }\end{array}$ & $\begin{array}{l}\text { Curettage; posterior } \\
\quad \text { fixation }\end{array}$ & $\begin{array}{l}\text { Asymptomatic at } 34 \text {-month } \\
\text { follow-up }\end{array}$ \\
\hline & M & 28 & No & $\mathrm{C} 2$ & Monostotic & $\begin{array}{l}\text { Curettage; anterior } \\
\text { fixation }\end{array}$ & $\begin{array}{l}\text { Asymptomatic at } 33 \text {-month } \\
\text { follow-up }\end{array}$ \\
\hline & M & 53 & Yes & $\mathrm{C} 7$ & Polyostotic & $\begin{array}{l}\text { Excision; anterior and } \\
\text { posterior fixation }\end{array}$ & $\begin{array}{l}\text { Asymptomatic at } 42 \text {-month } \\
\text { follow-up }\end{array}$ \\
\hline & M & 17 & Yes & $\mathrm{C} 2$ & Polyostotic & Posterior fixation & $\begin{array}{l}\text { Asymptomatic at } 28 \text {-month } \\
\text { follow-up }\end{array}$ \\
\hline Lee et al. [34] & M & 63 & Yes & $\mathrm{C} 4$ & Polyostotic & $\begin{array}{l}\text { Corporectomy; allograft; } \\
\text { posterior fixation }\end{array}$ & No follow-up \\
\hline Dang et al. [35] & M & 35 & Yes & $\mathrm{C} 2 / \mathrm{C} 3$ & Polyostotic & $\begin{array}{l}\text { Percutaneous } \\
\text { vertebroplasty }\end{array}$ & $\begin{array}{l}\text { Stable pain relief and } \\
\text { neurologic improvement } \\
\text { at } 12 \text {-month follow-up }\end{array}$ \\
\hline $\begin{array}{l}\text { Marshmann et al. } \\
\text { [13] }\end{array}$ & M & 35 & No & $\mathrm{C} 3$ & Monostotic & Corpectomy; fixation & $\begin{array}{l}\text { Asymptomatic at 18-month } \\
\text { follow-up }\end{array}$ \\
\hline Medow et al. [36] & $\mathrm{F}$ & 40 & No & C3 & Polyostotic & $\begin{array}{l}\text { Synthetic bone graft; } \\
\text { posterior fixation }\end{array}$ & $\begin{array}{l}\text { Asymptomatic at } 25 \text {-month } \\
\text { follow-up }\end{array}$ \\
\hline Mezzadri et al. [37] & $\mathrm{F}$ & 35 & No & $\mathrm{C} 5$ & Not stated & $\begin{array}{l}\text { Corporectomy; synthetic } \\
\text { graft; posterior fixation }\end{array}$ & $\begin{array}{l}\text { Asymptomatic at 36-month } \\
\text { follow-up }\end{array}$ \\
\hline Stompro et al. [38] & $\mathrm{M}$ & 26 & Not stated & $\mathrm{C} 2$ & Polyostotic & Immobilizer brace & No follow-up \\
\hline
\end{tabular}


FD is traditionally considered to stop growing in the mature skeleton, but this may not actually be the case, especially with polyostotic presentation [22, 23]. In a single case of FD involving $\mathrm{C} 2$ in a 21-year-old man who underwent posterior spinal fusion from $\mathrm{C} 1$ to $\mathrm{C} 3$ performed with use of two cortico-cancellous grafts from the posterior iliac crest, the routine radiography follow-up 20 years later demonstrated extension of the expansile lesion through the bone graft to $\mathrm{C} 3$, with the classical ground-glass appearance. MRI confirmed the extension of the FD lesion into the posterior elements of $\mathrm{C} 3$ through the fusion bone graft $[9,24]$.

Our case exhibited some aggressive radiological features, namely a pathological fracture of the odontoid process and an osteolytic area involving the inferior part of the $\mathrm{C} 2$ vertebral body, which led us to perform a guided biopsy for pathological evaluation. A locally aggressive variant of FD characterized by cortical destruction that mimics malignancy on CT and MRI has been described $[25,26]$. A large number of reported cases of locally aggressive FD involved the craniofacial skeleton, especially the maxilla and mandible in young patients $[25,27,28]$. Among the 14 cases of locally aggressive FD outside the skull previously reported, none was involving the spine [25, 26, 28-31].

Possible other causes of aggressive radiological patterns with cortical destruction and a soft tissue mass encountered in FD include malignant transformation and secondary aneurysmal bone cyst formation. Vertebral FD with secondary aneurysmal bone cyst formation is uncommon and usually manifests as an expanding lesion [32, 33]. Malignant transformation of vertebral FD is very uncommon and more frequent in polyostotic than monostotic FD [25]. Both secondary aneurysmal bone cyst formation and malignant transformation were absent in our case.

In conclusion, cervical FD may present in a young adult as a monostotic lesion, particularly in $\mathrm{C} 2$, with a pathological fracture and some aggressive radiologic features. In such cases, a ground-glass mineralization may suggest the diagnosis but a biopsy is required.

\section{Conflict of interest}

The authors declare that they have no conflict of interest.

\section{References}

1. Lichtenstein L (1938) Polyostotic fibrous dysplasia. Arch Surg 36(5), 874-898.

2. Harris WH, Dudley HR, Barry RJ (1962) The natural history of fibrous dysplasia: an orthopaedic, pathological, and roentgenographic study. J Bone Jt Surg 44(2), 207-233.

3. Dahlin DC, Unni KK. 1986. Bone tumors: general aspects and data on 8,547 cases, 4th edn. Thomas, USA. Available from https://www.osti.gov/scitech/biblio/5518830.

4. Schwindinger WF, Francomano CA, Levine MA (1992) Identification of a mutation in the gene encoding the alpha subunit of the stimulatory $G$ protein of adenylyl cyclase in
McCune-Albright syndrome. Proc Natl Acad Sci 89(11), 51525156.

5. Gibson MJ, Middlemiss JH (1971) Fibrous dysplasia of bone. Br J Radiol 44(517), 1-13.

6. Arantes M, Vaz AR, Honavar M, Resende M, Pereira JR (2008) Fibrous dysplasia of the first cervical vertebra. Spine 33(24), E933-E935.

7. Ehara S, Kattapuram SV, Rosenberg AE (1992) Fibrous dysplasia of the spine. Spine 17(8), 977-978.

8. Schoenfeld AJ, Koplin SA, Garcia R, et al. (2010) Monostotic fibrous dysplasia of the spine: a report of seven cases. J Bone Jt Surg Am 92(4), 984-988.

9. Hu SS, Healey JH, Huvos AG (1990) Fibrous dysplasia of the second cervical vertebra. A case report. JBJS 72(5), 781-783.

10. Ohki I (1990) Monostotic fibrous dysplasia in the spine. J West Pacif Orthop Assoc 27, 107-110.

11. Iwasaki M, Hida K, Yano S, Iwasaki Y (2008) Case of cervical monostotic fibrous dysplasia with a large cyst. No Shinkei Geka Neurol Surg 36(5), 429-433.

12. Stirrat AN, Fyfe S, Fisher CJ (1989) Fibrous dysplasia of the axis: a case report. Spine 14(2), 243-245.

13. Marshman LAG, David KM, O'Donovan DG, Chawda SJ (2004) Fibrous dysplasia of the cervical spine presenting as a pathological fracture. Br J Neurosurg 18(5), 527-533.

14. Schlumberger MHG (1946) Fibrous dysplasia of single bones (monostotic fibrous dysplasia). Mil Surg 99, 504-527.

15. Rosendahl-Jensen S (1956) Fibrous dysplasia of the vertebral column. Acta Chir Scand 111(6), 490-494.

16. Proschek D, Orler R, Stauffer E, Heini P (2007) Monostotic fibrous dysplasia of the spine: report of a case involving a cervical vertebra. Arch Orthop Trauma Surg 127(2), 75-79.

17. Villas C, Martínez-Peric R (1992) Monostotic fibrous dysplasia of a cervical vertebra. Eur Spine J 1(2), 137-139.

18. Sambasivan M, Sanalkumar P, Mahesh S, Nair K, Basheer A (2008) Monostotic fibrous dysplasia of the C4 cervical spine. Neurol India 56(4), 497-498.

19. Resnik CS, Lininger JR (1984) Monostotic fibrous dysplasia of the cervical spine: case report. Radiology 151(1), 49-50.

20. Wu FL, Jiang L, Liu C, et al. (2013) Fibrous dysplasia of the mobile spine: report of 8 cases and review of the literature. Spine 38(23), 2016.

21. Park SK, Lee IS, Choi JY, et al. (2012) CT and MRI of fibrous dysplasia of the spine. Br J Radiol 85(1015), 996-1001.

22. Chow LC, Griffith J, Chow WH, Kumta SM (2000) Monostotic fibrous dysplasia of the spine: report of a case involving the lumbar transverse process and review of the literature. Arch Orthop Trauma Surg 120(7-8), 460-464.

23. Proschek D, Orler R, Stauffer E, Heini P (2007) Monostotic fibrous dysplasia of the spine: report of a case involving a cervical vertebra. Arch Orthop Trauma Surg 127(2), 75-79.

24. Meredith DS, Healey JH (2011) Twenty-year follow-up of monostotic fibrous dysplasia of the second cervical vertebra. JBJS Case Connect 93(13), e74.

25. Yao L, Eckardt JJ, Seeger LL (1994) Fibrous dysplasia associated with cortical bony destruction: CT and MR findings. J Comput Assist Tomogr 18(1), 91.

26. Muthusamy S, Subhawong T, Conway SA, Temple HT (2015) Locally aggressive fibrous dysplasia mimicking malignancy: a report of four cases and review of the literature. Clin Orthop Relat Res 473(2), 742-750. 
27. Shapeero LG, Vanel D, Ackerman LV, et al. (1993) Aggressive fibrous dysplasia of the maxillary sinus. Skeletal Radiol 22(8), $563-568$.

28. Kashima TG, Gamage NM, Ye H, et al. (2013) Locally aggressive fibrous dysplasia. Virchows Arch 463(1), 79-84.

29. Dorfman HD, Ishida T, Tsuneyoshi M (1994) Exophytic variant of fibrous dysplasia (fibrous dysplasia protuberans). Human Pathol 25(11), 1234-1237.

30. Hermann G, Garcia R. 2013. Exophytic fibrous dysplasia of the rib. 4. Osteologiai Közlemények. Available from https:// www.google.com/search?q=hermann+exophytic+fibrous+ dysplasia+of+the+rib\&rlz=1C1CHBD_frFR838FR840\&oq= hermann+exophytic+fibrous+dysplasia+of+the+rib++\&aqs $=$ chrome..69i57.91767j0j7\& sourceid=chrome\&ie= UTF-8.

31. Latham PD, Athanasouz NA, Woods CG (1992) Fibrous dysplasia with locally aggressive malignant change. Arch Orthop Trauma Surg 111(3), 183-186.

32. Snieders MN, van Kemenade FJ, van Royen BJ (2009) Monostotic fibrous dysplasia of a lumbar vertebral body with secondary aneurysmal bone cyst formation: a case report. J Med Case Rep 3(1), 7227.
33. Sharifudin MA, Zakaria Z, Awang MS, Mohamed Amin MA, Abd Aziz A (2016) A rare case of monostotic spinal fibrous dysplasia mimicking solitary metastatic lesion of thyroid carcinoma. Malays J Med Sci 23(1), 82-86.

34. Lee SH, Han IH, Kang DW, Choi BK (2011) Cervical fibrous dysplasia presenting as a pathologic fracture in an older patient. J Kor Neurosurg Soc 50(2), 139-142.

35. Dang D, Baig MN, Christoforidis G, Chiocca EA, Gabriel J (2007) C2/C3 pathologic fractures from polyostotic fibrous dysplasia of the cervical spine treated with percutaneous vertebroplasty. Eur Spine J 16(3), 250-254.

36. Medow JE, Agrawal BM, Resnick DK (2007) Polyostotic fibrous dysplasia of the cervical spine: case report and review of the literature. Spine J 7(6), 712-715.

37. Mezzadri JJ, Acotto CG, Mautalen C, Basso A (1999) Surgical treatment of cervical spine fibrous dysplasia: technical case report and review. Neurosurgery 44(6), 1342-1346.

38. Stompro BE, Alksne JF, Press GA (1989) Diagnosis and treatment of an odontoid fracture in a patient with polyostotic fibrous dysplasia: case report. Neurosurgery 24(6), 905-909.

Cite this article as: Milon A, Polivka M, Larousserie F, Lot G, Ziza J-M \& Laredo J-D (2019) Locally aggressive monostotic fibrous dysplasia of the cervical spine mimicking malignancy: a case report and literature review. SICOT-J 5, 34 